\title{
Comportamiento mecánico de columnas de hormigón armado reforzadas con mortero reoplástico
}

\section{Mechanical behavior of concrete columns reinforced with rheoplastic mortar}

\author{
D. Foti $(*)$, S. Vacca $(*)$
}

Recepción/Received: 18-VII-12

Aceptación/Accepted: 6-XI-12

Publicado online/Online publishing: $12-\mathrm{XI}-12$

\section{RESUMEN}

La presente investigación se inscribe dentro de la temática general de la rehabilitación de edificios existentes, en particular a las estructuras de hormigón.

Se han realizado una serie de ensayos con el objetivo de definir la mejor solución para el refuerzo de una estructura deteriorada mediante la utilización de morteros reoplásticos.

Se han considerado tres posibles tipos de refuerzo estructural sobre los pilares de hormigón armado, prestando especial atención a la adherencia entre materiales con diferentes propiedades físico-químicas y características mecánicas de los mismos.

Se han analizado los patrones de grietas obtenidos en las probetas con el fin de demostrar la relevancia del espesor del refuerzo en la obtención de un comportamiento mecánico efectivo del hormigón armado a largo plazo.

Palabras clave: columnas; hormigón armado; resistencia; ensayo de materiales.

\section{SUMMARY}

The present research fits in the general thematic of the renovation of existing buildings in particular concrete structures.

A series of tests have been performed with the aim to define the best solution in strengthening a deteriorated structure with a rheoplastic mortar reinforcement.

Three types of possible structural reinforcing renovation on reinforced concrete pillars have been considered, with special attention to adhesion between materials with different chemical-physical and mechanical characteristics.

The crack patterns obtained on the specimens have been analyzed to demonstrate the relevance of an appropriate thickness of the reinforcement to obtain an effective mechanical behavior of the reinforced concrete element over time.

Keywords: columns; concrete structures; strength; testing of materials.

(*) Technical University of Bari (Bari, Italia). 


\section{INTRODUCTION}

En la actualidad el uso de morteros reoplásticos para la consolidación y mejora de las estructuras se está utilizando cada vez más. En concreto, esta tipo de mortero es capaz de mejorar la resistencia de los elementos estructurales de mampostería y de las estructuras de hormigón a diferencia de lo que sucede con los morteros de cementos ordinarios (1).

Particularmente, en el caso de estructuras de hormigón armado con bajas características desde el punto de vista de la durabilidad, en las que se hacen necesarias sucesivas intervenciones en los elementos afectados por el deterioro, se pueden producir reducciones en las resistencias estáticas y dinámicas, y consecuentemente, reducciones de la capacidad de carga global.

La durabilidad de los materiales de construcción es, en la actualidad, un problema típico y altamente difundido. Es un problema complejo que puede estar relacionado con las causas del proceso de degradación de edificios completos o partes de ellos. La durabilidad está también relacionada con la posibilidad de garantizar a largo plazo, el comportamiento de un material en un determinado lugar (o del material utilizado para en la restauración). La durabilidad es tan importante como otros factores, y por lo tanto, debe ser considerada como un punto de referencia de diseño a tener en cuenta de forma cuidadosa para mantener el uso de la construcción durante su vida útil sin necesidad de un mantenimiento no programado.

La posibilidad de no alterar la durabilidad del hormigón armado en la restauración de edificios, podría alcanzase mediante el uso de morteros reoplásticos. Estos morteros están normalmente asociados con el refuerzo con materiales compuestos, tales como los de fibra de carbono. Un ejemplo de intervención estructural mediante el uso de morteros reoplásticos es el refuerzo estructural de la iglesia de Roma: "Basilica dei Santissimi Incoronati". Este consistió en la consolidación de las bóvedas de crucería de la iglesia mediante el uso de un material de refuerzo compuesto con fibras de carbono y mortero reopástico.

Otra posible asociación de estos morteros, todavía bajo estudio, es mediante el uso de hormigones compuestos con adiciones de fibras PET procedentes de botellas recicladas tales como las de agua mineral o para el refuerzo de mamposteria $(2,3)$.

En el presente artículo se analiza desde el punto de vista teórico y experimental, el comportamiento de elementos de hormigón reforzados mediante morteros reoplásticos.

El objetivo es lograr una compresión detallada de la interacción entre un elemento de hormigón armado, que puede asimilares a una columna convencional, y un

\section{INTRODUCTION}

In recent years the use of rheoplastic mortars for consolidation and reinforcement is increasing. This kind of mortar, in fact, is capable to increase the strength of structural elements in masonry structures and reinforced concrete structures if compared to ordinary cement mortar (1).

In particular, reinforced concrete structures pointed out low characteristics in terms of durability, with subsequent need of repeated structural interventions on elements affected by deterioration, which could produce reduction of the static and dynamic strength and, consequently, a global bearing capacity reduction.

A typical and diffuse problem of the construction technology of our times is, in fact, the durability of building materials. It is a complex issue that may relate to the causes that produce a state of degradation of a particular building or part of it. Durability is also related to the possibility to ensure the same material in place (or the material used to restore) a permanent behavior over time. Durability becomes as important as other factors, and, therefore, should be considered as an important desing datum to keep a building operating in its lifetime without the need of unplanned maintenance.

The possibility not to affect the durability of reinforced concrete could be reached by the use of rheoplastic mortars for the restoration of buildings. They are usually coupled with composite reinforcing materials such as those with carbon fibers. For example a structural intervention by the use of rheoplastic mortar is the structural reinforcement of a church in Rome: "Basilica dei Santissimi Quattro Incoronati". It consisted in the consolidation of the cross vaults of the church by using a composite reinforcing material with carbon fibers and rheoplastic mortar.

Another possible coupling of these mortars, still under stu$d y$, is with the use of composite concretes made with the addition of PET fibers from waste bottles such as those for mineral water, or for the strengthening of masonry $(2,3)$.

In the present paper, the behavior of concrete elements reinforced by the use of rheoplastic mortars is analyzed from a theoretical and experimental point of view.

The objective is a detailed understanding of the interaction between a reinforced concrete element, which can recognize itself in a regular column and a reinforcing element 
elemento de refuerzo, hecho mediante mortero reoplástico, estudiada en sus formas de uso más comunes.

Las propiedades mecánicas del hormigón y sus aplicaciones potenciales, especialmente en combinación con refuerzos de acero, permitió a este material un desarrollo excepcional en la ingeniería y la arquitectura (4).

Sin embargo, hay que destacar que, hasta la fecha, no hay ningún material que envejezca tan rápidamente como el hormigón, aunque es posible ver ejemplos de estructuras realizadas con este material que han sobrevivido al paso del tiempo. Esto significa que cuando el conocimiento se aplica con diligencia y cuidado, los resultados esperados se han logrado mediante el envejecimiento natural.

\section{INTERFAZ MECÁNICA ENTRE MATERIALES CEMENTANTES}

\subsection{Caracterización de la interfaz mecánica}

Generalmente, el término "interfaz" se refiere al límite entre dos materiales diferentes, sin considerar la zona de transición entre el material de la matriz cargada y el refuerzo, que es la zona más porosa y menos rígida del material de matriz cargada. La interfaz se configura como una región importante que debe ser incluida en el análisis teórico.

Para modelar la zona de transición se puede utilizar la relación constitutiva propuesta por Steif y Hoysan (1986) (5).

Es importante destacar que en el presente estudio la interfaz siempre se representará como una superficie en el análisis en tres dimensiones y una línea o curva en el análisis en dos dimensiones.

\subsection{La interfaz en los materiales compuestos}

Desde el punto de vista mecánico, la interfaz en compuestos cementantes puede ser definida usando tres modelos diferentes (6).

Una interfaz sin problemas de unión se puede interpretar físicamente como una unión química y/o física, entre el núcleo del material reforzado y el propio material de refuerzo (mortero reoplástico). Esta unión es suficientemente fuerte para asegurar la continuidad de las tensiones y las deformaciones a través de la interfaz, para el caso de una carga externa aplicada en el sistema. La descripción de una unión perfecta en la interface implica una unión viscosa de carácter químico o físico, entre los dos materiales analizados. made in rheoplastic mortar, studied in its most common usage patterns.

The mechanical properties of concrete and its potential applications, especially in combination with steel reinforcement, allowed to this material an exceptional development in engineering and architecture (4).

However it must be stressed that, to date, there is no material that has aged so early as concrete, even if it is possible to see examples of structures made with this material survived the ravages of time. This means that where the knowledge is being applied with diligence and care, expected results have been achieved by recording only a natural aging.

\section{MECHANICAL INTERFACE IN CEMENTITIOUS MATERIALS}

\subsection{Mechanical interface characterization}

Usually, the term "interface" refers to the boundary between two different materials, not considering the transition zone between the loaded matrix material and the reinforcing one that is the most porous and less rigid area of the loaded matrix material. The interface is configured as an important region to be included in the theoretical analysis.

To model the transition zone a special constitutive relation for the interface can be used, such as the one obtained by the procedure suggested by Steif and Hoysan (1986) (5).

It is important to note that in the present study the interface will always indicate a surface in the three-dimensional analysis and a line or a curve in the two-dimensional analysis.

\subsection{The interface in composite materials}

From the mechanical point of view the interface in cementitious composites can be defined using three different models (6).

An interface seamlessly linked can be physically interpreted as the one where a chemical (and/or a physical bond) is established between the central core and the reinforcing material (rheoplastic mortar). This bond is strong enough to ensure the continuity of stress and displacement across the interface, given an external load applied to the system. The description of a perfectly tied interface implies a viscous tie of chemical and/or physical nature between the two materials into consideration. 
Una interfaz desconectada puede ser interpretada como una unión provisional entre las dos partes, debida a las cargas que actúan sobre ellas. En la interfaz desconectada, la caracterización del material se ha modificado de una unión por continuidad a una unión por condiciones límite entre fuerzas y desplazamientos a lo largo de la dirección tangencial de la unión $\left(\tau_{r}=\tau_{m}=f, u_{r}=u_{m}\right.$ $=g$ donde $f$ y $g$ representan la fuerza de fricción y/o la fuerza de adherencia).

En el caso de interfaz cohesiva, o interfaz adhesiva, se asume que la transmisión de fuerzas es siempre mediante un desplazamiento relativo entre los dos materiales (se deduce, por tanto, que no hay unión física y/o química) (7). Consecuentemente, el modelo de interfaz cohesiva puede ser físicamente interpretado como una interfaz sin adherencia, pero con tensiones debidas a la rugosidad. Las tensiones generadas en la interfaz son debidas al desplazamiento relativo entre la superficie del material de refuerzo y la matriz.

\section{ENSAYOS DE LABORATORIO}

\subsection{Caracterización de los materiales}

Se ensayaron a compresión un total de 30 probetas reforzadas en los laboratorios "M. Salvati" del Departamento de Ingeniería Civil y Arquitectura de la Universidad Politécnica de Bari, Italia.

Se ensayaron probetas cilíndricas de hormigón con recubrimiento anular de mortero con igual coeficiente de Poisson que el hormigón utilizado en el núcleo, pero con $\mathrm{R}_{\mathrm{ck}}$ de valor $60 \div 70 \mathrm{~N} / \mathrm{mm}^{2}$.

Las probetas se realizaron en el laboratorio y consistían en dos zonas homogéneas con propiedades mecánicas y químicas diferentes.

Como sistema de referencia se utilizó un sistema en coordenadas cilíndricas $(r, \theta, z)$. Bajo este sistema de coordenadas, las condiciones de carga son de simetría axial. Por lo tanto, un punto genérico de la superficie lateral solo tendrá componente axial, $u_{r r}$ y no componente tangencial, $u_{\theta}$

Las características de las probetas de hormigón, sin ningún tipo de refuerzo, mostraron las siguientes características:

- $\mathrm{R}_{\mathrm{C}}=27,78 \mathrm{~N} / \mathrm{mm}^{2}$;

- resistencia a tracción indirecta $=2,25 \mathrm{~N} / \mathrm{mm}^{2}$;

- $E=26.000 \mathrm{~N} / \mathrm{mm}^{2}$;

- coeficiente de Poisson, $v=0,24$;

- altura, $\mathrm{h}=30 \mathrm{~cm}$;

- diámetro $=16 \mathrm{~cm}$.
A disunited interface can be interpreted as the one provisionally linked, loaded over the force that joined the two parts. On the detached interface the material characterization has been changed from a condition of continuity to a boundary condition in the forces and displacements along the tangential direction $\left(\tau_{r}=\tau_{m}=f, u_{r}=u_{m}=\right.$ $g$ where $f$ and $g$ represent the friction and/or adherence strength).

In the cohesive interface, or adhesive interface, it is assumed that the transfer of strength is always connected to the relative displacement between the two materials (it follows, therefore, that there is no physical and/or chemical viscous link) (7). Consequently, the interface cohesive model can be physically interpreted as an interface with no adhesion, but with an interface stress that is associated to the roughness. As a result a relative displacement between the surface of the reinforcement and the matrix causes the development of an interfacial stress.

\section{LABORATORY TESTS}

\subsection{Specimens characterization}

A series of compression tests have been performed on 30 reinforced specimens in the testing laboratory " $M$. Salvati" of the Department of Civil Engineering and Architecture of the Technical University of Bari in Italy.

The specimens consist in a concrete cylinder core and an external circular mortar ring with the same Poisson's ratio of the concrete but with $R_{c k}$ equal to $60 \div 70 \mathrm{~N} / \mathrm{mm}^{2}$.

The specimens were built in the laboratory and consisted of two homogeneous regions with different chemical and physical mechanical properties.

The reference system considered has cylindrical coordinates $(r, \theta, z)$. In this reference system the load condition is axial-symmetric, as a generic point of the lateral surface will have only the axial component $u_{r}$ and not the tangential one $u_{\theta}$.

The specimens, prepared in the laboratory for the tests, showed the following characteristics for the cylinder core:

- $R_{C}=27.78 \mathrm{~N} / \mathrm{mm}^{2}$;

- Indirect tensile strength $=2.25 \mathrm{~N} / \mathrm{mm}^{2}$;

- $E=26000 \mathrm{~N} / \mathrm{mm}^{2}$;

- Poisson's ratio, $v=0.24$;

- height, $h=30 \mathrm{~cm}$;

- diameter $=16 \mathrm{~cm}$. 
La capa de mortero aplicada como refuerzo perimetral en la superficie de la probeta era de $2 \mathrm{~cm}$ de espesor, con altura variable (8).

Se analizaron tres esquemas para el refuerzo estructural de pilares de hormigón según el tipo de intervención posible en la estructura, tal y como se puede ver en la Figura 1.
The external mortar ring has a thickness of $2 \mathrm{~cm}$, with a variable height (8).

Three types of possible interventions on the structural strength of reinforced concrete pillars have been simulated utilizing the three types of specimens shown in Figure 1.

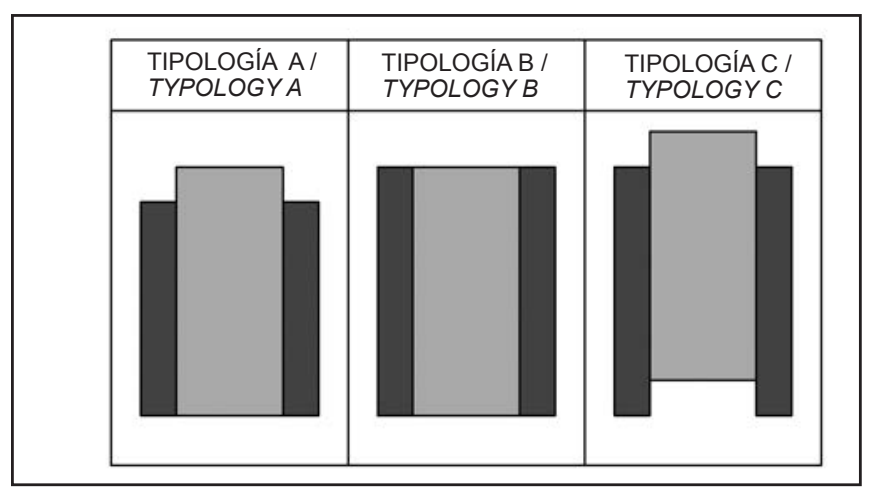

Figura 1. Tipologías de refuerzo estructural de probetas de hormigón mediante mortero. Figure 1. Typologies of the specimens for different mortar reinforcement.

En el primer esquema de refuerzo (Tipología A, Figura 1) se dotó de una altura de refuerzo con mortero de $25 \mathrm{~cm}$, permitiendo que el núcleo de la probeta de hormigón sobresaliera $2 \mathrm{~cm}$ de la zona reforzada. Se pretendía simular el caso real en el que es posible la aplicación del refuerzo en la base del pilar, pero es imposible en la parte superior del mismo debido a la presencia de vigas y/o losas.

En el segundo esquema de refuerzo (Tipología B, Figura 1) se dotó de una altura de refuerzo con mortero de $30 \mathrm{~cm}$, correspondiente a la altura total del núcleo de la probeta de hormigón. En este caso, se pretendía simular la situación ideal de refuerzo de la estructura aplicando el mortero tanto en la base del pilar, como en la parte superior del mismo. Este tipo de refuerzo no es habitual debido a que en la intervención para el refuerzo del pilar, se debe afectar a las vigas y/o losas de la estructura.

En el tercer esquema de refuerzo, según la Tipología C, se dotó de una altura de refuerzo de mortero de $30 \mathrm{~cm}$, igual a la altura total del núcleo de la probeta de hormigón pero desplazada inferiormente $2 \mathrm{~cm}$ (Figura 1). Esta tipología se ha elegido para estudiar el comportamiento mecánico de la interfaz entre los dos materiales.

Las probetas analizadas se reforzaron con dos tipologías de mortero. El primer tipo de mortero, utilizado en aplicaciones de restauración, es EMACO S88 para uso vertical. Este mortero es de tipo reoplástico expansivo (compensated shrinkage), resistente a sulfatos, con altos valores de resistencia mecánica y adherencia, así como impermeable
The first type of specimens (Typology A, Figure 1) provides a mortar height of $28 \mathrm{~cm}$, allowing the core to emerge of $2 \mathrm{~cm}$ from the reinforcement. A real case has been simulated where it is possible to apply the reinforcement on the foot of the pillar, but it is not possible on the top because of the presence of beams and/or floors.

The second type of specimens (Typology B, Figure 1) provides a mortar height equal to the central core that is $30 \mathrm{~cm}$. In this way the ideal case of a reinforcing applied both to the foot and on the top is simulated. This event is uncommon because in the intervention the beam and/or the floor should be raised.

The third type of test on Typology C specimens provides a mortar height equal to the central core that is $30 \mathrm{~cm}$, with an offset of the two bodies of $2 \mathrm{~cm}$ (Figure 1). This typology has been chosen to study the mechanical behavior at the interface between the two materials.

The specimens have been prepared using for the reinforcement two types of mortars. The first type of mortar for structural restoration applications is EMACO S88 pourable type. It is a sulphate-resistant rheoplastic mortar with a compensated shrinkage, high mechanical and adhesive strength, waterproof and very durable. Its compressive 
y resistente a largo plazo. Presenta una resistencia a compresión a los 28 días de valor $R_{c}=70 \mathrm{~N} / \mathrm{mm}^{2}$ y a flexión a los 28 días de $8 \mathrm{~N} / \mathrm{mm}^{2}$.

El segundo tipo de mortero utilizado es EMACO CFR S150, reforzado con fibras y de carácter expansivo (compensated shrinkage). Este mortero es autonivelante con altos valores de resistencia mecánica y durable. La resistencia a compresión a los 28 días es $\mathrm{R}_{\mathrm{c}}=60 \mathrm{~N} / \mathrm{mm}^{2}$, y la resistencia a flexión a los 28 días es $18 \mathrm{~N} / \mathrm{mm}^{2}$.

Las dos tipologías de mortero analizadas presentan malas propiedades de aplicación en el caso de hormigones frescos o en contacto con agua con $\mathrm{pH}<5,5$.

\subsection{Dispositivos de ensayo}

El ensayo de compresión se realizó mediante una prensa de $3.000 \mathrm{kN}$ tipo 66 con sistema de control automático de aplicación de la carga, equipada con pistón central.

Las probetas se han instrumentado mediante galgas extensométricas en posición vertical y horizontal, habiéndose producido el registro de la información mediante una tarjeta de adquisición de datos con 16 canales. La Figura 2 muestra una probeta sometida al ensayo de compresión, así como la configuración de galgas utilizadas. strength after 28 day is $R_{C}=70 \mathrm{~N} / \mathrm{mm}^{2}$ and its flexural strength after 28 days is $8 \mathrm{~N} / \mathrm{mm}^{2}$.

The second type is EMACO CFR S150, a fiber-reinforced cement mortar with a compensated shrinkage. It is a pourable self-leveling composite cement mortar with high mechanical strength and durability. Its compressive strength after 28 day is $R_{C}=60 \mathrm{~N} / \mathrm{mm}^{2}$ and its flexural strength after 28 days is $18 \mathrm{~N} / \mathrm{mm}^{2}$.

Both types of mortar are not good to be applied on fresh concrete or in contact to water with $\mathrm{pH}<5.5$.

\subsection{Test equipment}

The compression tests have been performed on a 3000 $K N$ press of type 66 with an automatic control of the load gradient. It is equipped with a central piston.

Specimens have been instrumented with vertical and horizontal strain gauges; the data have been collected by an acquisition board with 16 channels. Figure 2 shows a specimen instrumented with strain gauges and installed in the loading equipment.

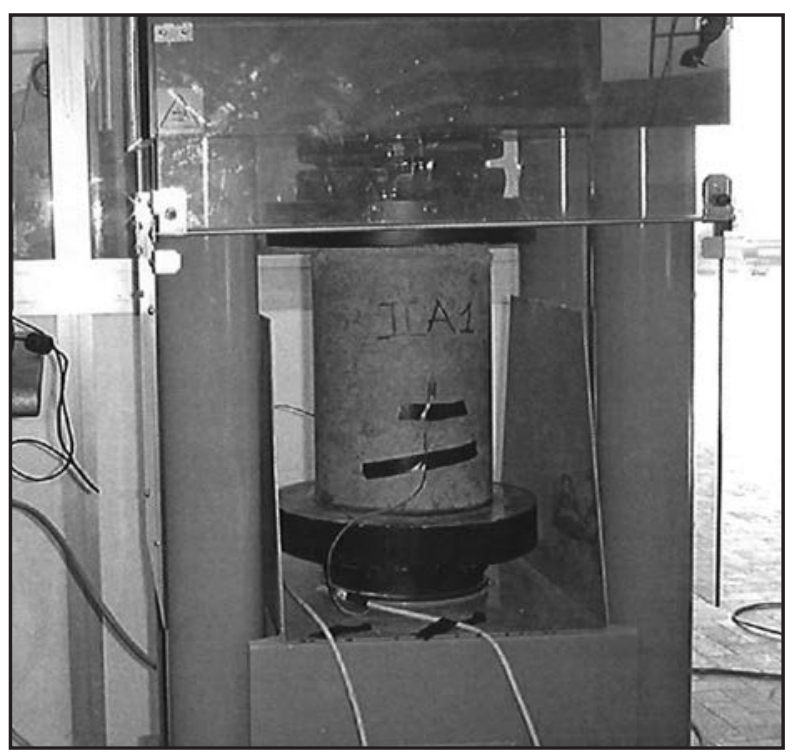

Figura 2. Equipo utilizado para el ensayo de compresión. Figure 2. Equipment utilized for the compression tests.

\subsection{Resultados}

Los resultados del ensayo de compresión en las probetas con el esquema de refuerzo $A, B, C$ y con motero EMACO S88, o EMACO S150 CFR se muestran en la Tabla 1.

\subsection{Results of the tests}

The results of the compression tests performed on the specimens of Typology $A, B$ and $C$ reinforced with mortar EMACO S88 and EMACO S150 CFR are shown in Table 1. 
Tabla 1 / Table 1

Carga de inicio de fisuración y carga de rotura para las probetas con esquemas de refuerzo Tipo A, B, y C (solo carga de inicio de fisuración).

First crack load and load at failure on specimens of Typology A, B and C (only first crack load).

\begin{tabular}{|c|c|c|c|c|c|c|c|}
\hline Efecto / Effect & Mortero / Mortar & Tipolog & ology $A$ & Tipologí & ology B & Tipologí & ology C \\
\hline \multirow{6}{*}{$\begin{array}{l}\text { Carga de inicio de fisuración } \\
\text { (kN) / First cracking load (kN) }\end{array}$} & \multirow{3}{*}{ EMACO S88 } & $\mathrm{IA} 1$ & 180 & I B1 & 372 & $\mathrm{IC} 1$ & 251 \\
\hline & & $\mathrm{IA} 2$ & 249 & I B2 & 383 & I C2 & 235 \\
\hline & & I A3 & 155 & I B3 & 288 & IC3 & 159 \\
\hline & \multirow{3}{*}{ EMACO CFR S150 } & II A1 & 360 & II B1 & 510 & II C1 & 331 \\
\hline & & II A2 & 310 & II B2 & 470 & II C2 & 221 \\
\hline & & II A3 & 342 & II B3 & 550 & II C3 & 234 \\
\hline \multirow{6}{*}{$\begin{array}{l}\text { Carga de rotura }(\mathrm{kN}) \text { / } \\
\text { Load at failure }(k N)\end{array}$} & \multirow{3}{*}{ EMACO S88 } & $\mathrm{IA} 1$ & 505 & I B1 & 628 & & \\
\hline & & $\mathrm{IA} 2$ & 518 & I B2 & 667 & & \\
\hline & & I A3 & 512 & I B3 & 534 & & \\
\hline & \multirow{3}{*}{ EMACO CFR S150 } & II A1 & 736 & II B1 & 651 & & \\
\hline & & II A2 & 530 & II B2 & 576 & & \\
\hline & & II A3 & 534 & II B3 & 731 & & \\
\hline
\end{tabular}

En dicha tabla, se muestran los resultados del valor de la carga de compresión en el momento de aparición de la primera fisura en la probeta (carga de inicio de fisuración), así como también el valor de la carga cuando se produce el colapso completo de la probeta (carga de rotura). Para el refuerzo Tipo $\mathrm{C}$, los valores mostrados en la tabla se refieren al valor de la carga a partir de la cual se produce el deslizamiento entre materiales, la cual se da simultáneamente con el inicio de fisuración.

En la Tabla 1, los resultados para los diferentes esquemas de refuerzo de las probetas son distintos porque estas se cargaron de forma diferente, por lo tanto, los valores obtenidos no son comparables. De todas formas, pueden extraerse las siguientes consideraciones.

En relación a las probetas reforzadas según la Tipología C, los valores medios de la carga de rotura son, tanto para el mortero EMACO S88, como para el mortero EMACO S150 CFR, $215 \mathrm{kN}$ y $262 \mathrm{kN}$, respectivamente. Las tensiones de adherencia en la interfaz son 1,5 N/mm², y 1,9 N/mm², respectivamente. Estos valores son una aproximación, debido a que por efecto de la carga vertical, las tensiones en la interfaz se inclinan hacia el interior del revestimiento de mortero cilíndrico. De hecho, el efecto de la adherencia genera una distribución cónica de tensiones (Figura 3). La componente horizontal de dichas tensiones produce una distribución de tensiones hidrostática, absorbida por el mortero de refuerzo. La componente vertical podría hacer que la parte externa del cilindro deslizase respecto al núcleo de hormigón. Los valores obtenidos están referidos solo a la componente vertical, por lo tanto, son una aproximación y están indicados como valores medios.

De los resultados de los ensayos, queda claro que la tipología con los mayores valores de resistencia es la tipología B. El refuerzo completo del núcleo de hormigón permite mantener un elevado nivel de contacto entre los
In the table the results at which the first crack appears in the specimen (first crack load) and when the specimen completely collapses (load at failure) are reported. For Type $C$ the values refer also to the scrolling load of the specimen that happens at the same time the first crack appears.

In Table 1 the results for the distinct typologies are distinct because the specimens are loaded in a different way and, consequently, the findings are not comparable. Anyway some considerations can be drawn in the following.

Referring to Typology $C$ specimens, the mean values of the load at failure are, for EMACO S88 and EMACO S150 CFR, respectively, $215 \mathrm{kN}$ and $262 \mathrm{kN}$. The corresponding adherence stresses at the interface surface are $1.5 \mathrm{~N} / \mathrm{mm}^{2}$ and $1.9 \mathrm{~N} / \mathrm{mm}^{2}$. These values are an approximation as, for effect of the vertical load the stresses at the interface are inclined towards inside the mortar coating cylinder. In fact the adherence effect results as a conical distribution (Figure 3). The horizontal component of this stress produces a hydrostatic distribution of stresses absorbed by the mortar reinforcement; the vertical component could make the external cylinder slip respect to the concrete core. The values obtained are referred only to the vertical component; therefore they are an approximation and are indicated as mean values.

From the results of the tests it is clear that the typology with the highest resistance values is typology $B$. The whole reinforcement of the concrete core allows, in fact, to maintain a high degree of continuity between the different 


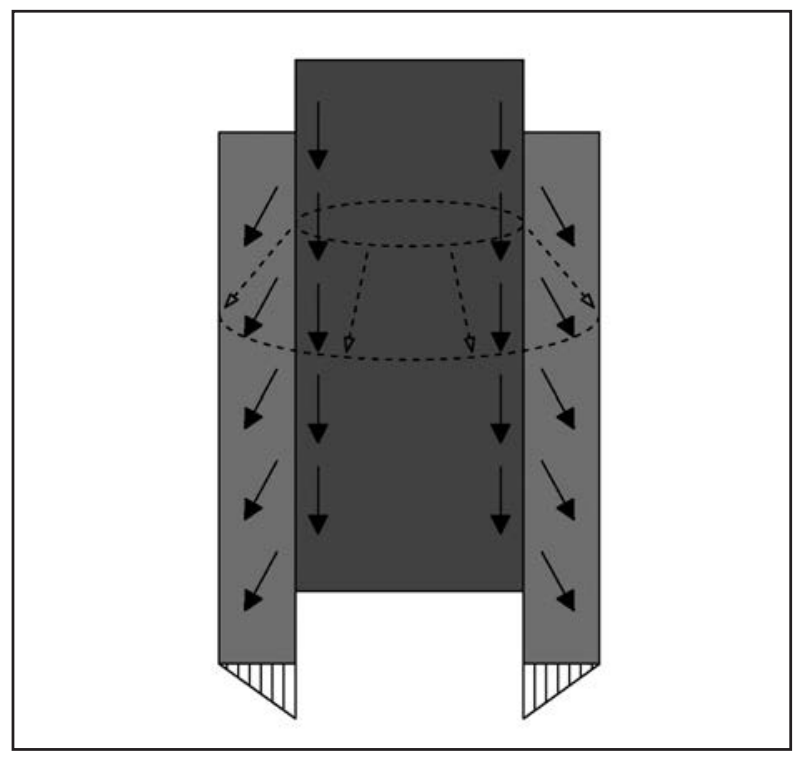

Figura 3. Distribución de tensiones en el revestimiento cilíndrico de mortero.

Figure 3. Distribution of stresses in the external mortar coating cylinder.

diferentes materiales, obteniéndose muy buenos resultados. Los valores de la carga de rotura para las probetas son mucho mayores que las obtenidas para las otras tipologías y en muchos casos, los valores registrados eran del orden del doble.

Sin embargo, un claro aumento en la resistencia depende de la carga de rotura de las probetas (comparación entre las Tipologías A y B), debido a que entra en juego la resistencia global del elemento. Por eso el aumento de refuerzo utilizando la Tipología B es mínimo en comparación con la totalidad de la capa cilíndrica de mortero de reopástico utilizado.

También es necesario señalar que aunque fuera fácil de predecir, los casos con un menor nivel de comportamiento plástico se corresponden con la Tipología C. Además, desde el punto de vista de la mejora de resistencia, el esquema de refuerzo más beneficioso se corresponde con la Tipología B.

Por lo tanto, los resultados experimentales obtenidos muestran un mejor comportamiento cuando el refuerzo se aplica en toda la superficie exterior del elemento degradado, lo que confirma la necesidad de reforzar el elemento en su totalidad con el fin de obtener un incremento adecuado de la resistencia.

Las Figuras 4, 5, 7, 9 y 11 muestran las curvas FuerzaDeformación, así como las cargas críticas para diferentes tipos de probetas. Las Figuras 6, 8, 10 y 12 muestran las fotos de diferentes probetas después de realizar los ensayos, en las cuales puede apreciarse claramente el desarrollo de las fisuras. materials, leading to very good results. The values of the cracking load for the specimen are, in fact, much higher than those obtained for the other typologies and in many cases the recorded data are doubled.

However, such a clear increase in resistance depends on the cracking load of the specimens (comparison between $A$ and $B$ Typologies) because coming into play the overall resistance of the element, the larger amount of reinforcement used in Typology $B$ is minimal when compared to the whole cylindrical layer made by rheoplastic mortars.

It is also necessary to point out that, although it was easy to predict, the case with a lower yield performance, in terms of overall strength compared to the tests carried out, turns out to be Typology $C$, while the geometry of reinforcement more beneficial from the point of view of resistance is Typology $B$.

Therefore, the reported experimental results show a better performance when the strengthening is applied on the entire outer surface of the degraded element, thus confirming the need to strengthen the whole element in order to obtain adequate increments of resistance.

Figures 4, 5, 7, 9 and 11 show the load-strain plots where deformation and critical loads for different types of specimens are evidenced. Figures 6, 8, 10 and 12 show the photos of the samples after the tests, where the crack pattern is quite clear. 


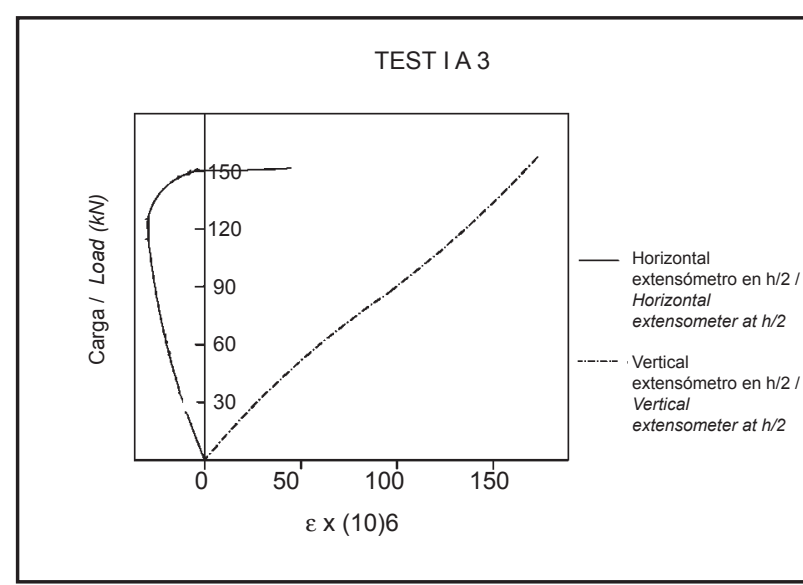

Figura 4. Curva Carga-Deformación. Probeta A3. Test I. Figure 4. Load-deformation behavior of specimen A3 during Test I.

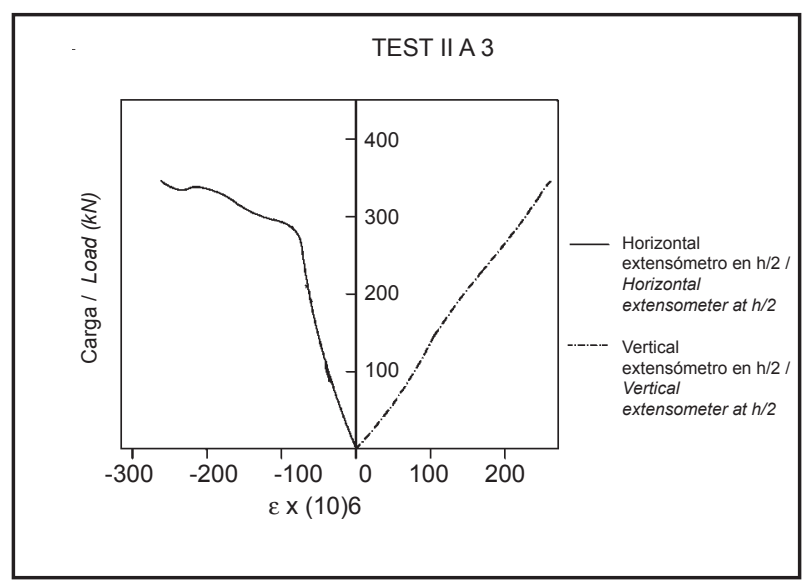

Figura 5. Curva Carga-Deformación. Probeta A3. Test II. Figure 5. Load-deformation behavior of specimen A3 during Test II.

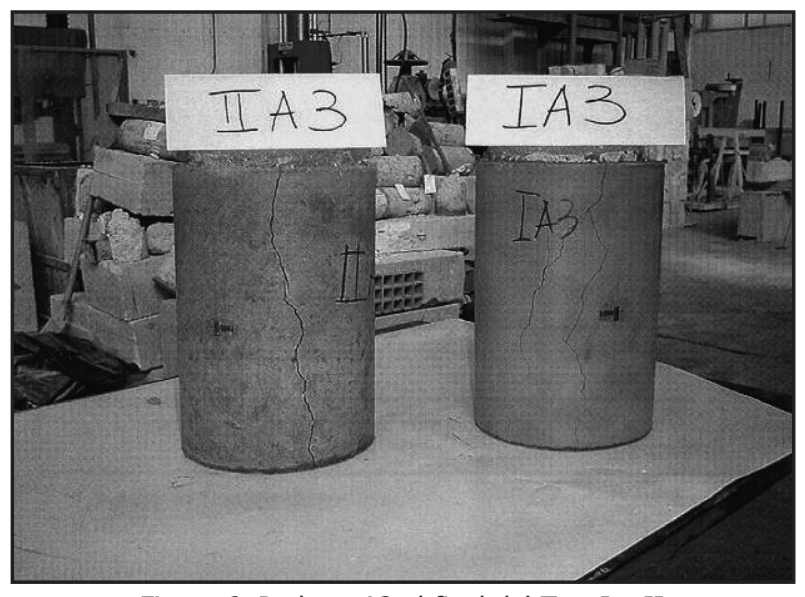

Figura 6. Probeta A3 al final del Test I y II.

Figure 6. Specimen A3 at the end of Tests I and II.

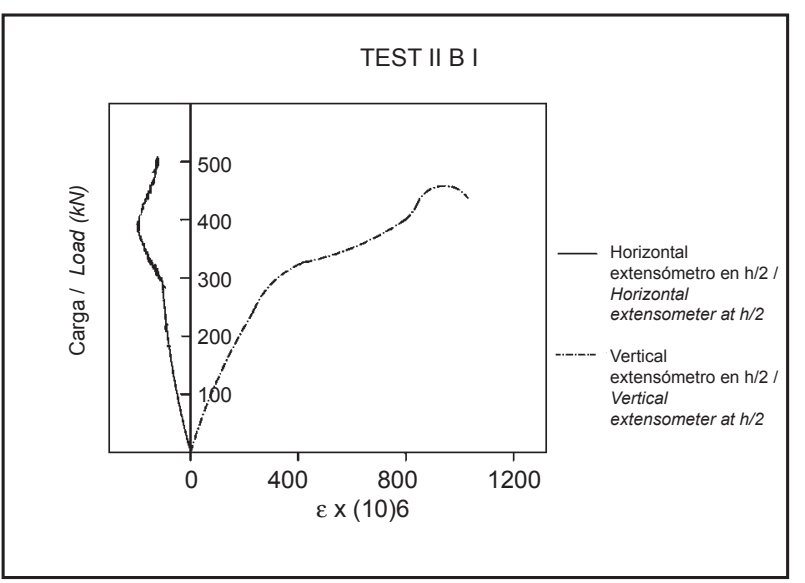

Figura 7. Curva Carga-Deformación. Probeta B1 Test II. Figure 7. Load-deformation behavior of specimen B1 during Test II.

Tras el análisis del desarrollo de las fisuras aparecidas en las probetas analizadas, se destaca que existe una tendencia a producirse una misma tipología en todas ellas, a pesar de haberse producido para diferentes valores de carga (mayores para el mortero EMACO CFR S150).

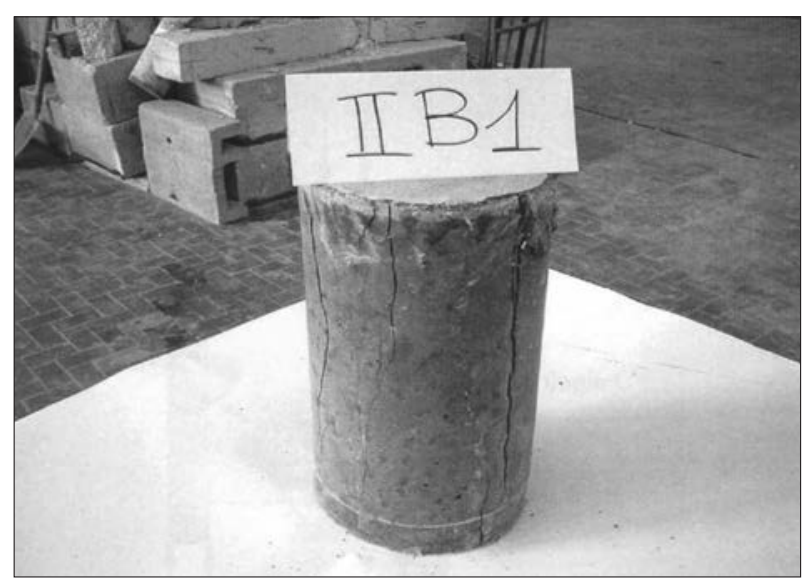

Figura 8. Probeta B1 al final del Test II. Figure 8. Specimen B1 at the end of Test II.

In the analysis of the crack patterns appeared on the samples tested, some cracks common to all typologies are evident, although they are due to different values of the load (higher for EMACO CFR S150 mortar). 


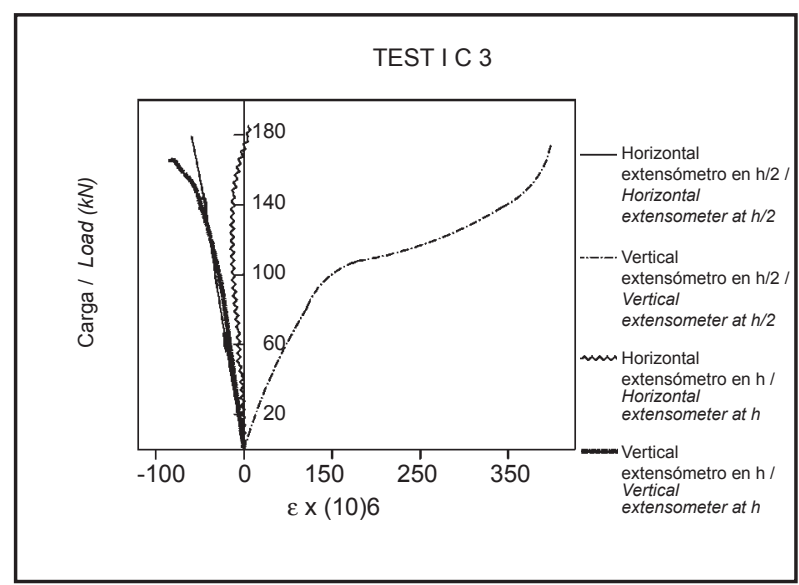

Figura 9. Curva Carga-Deformación. Probeta C3 Test I. Figure 9. Load-deformation behavior of specimen C3 during Test I.

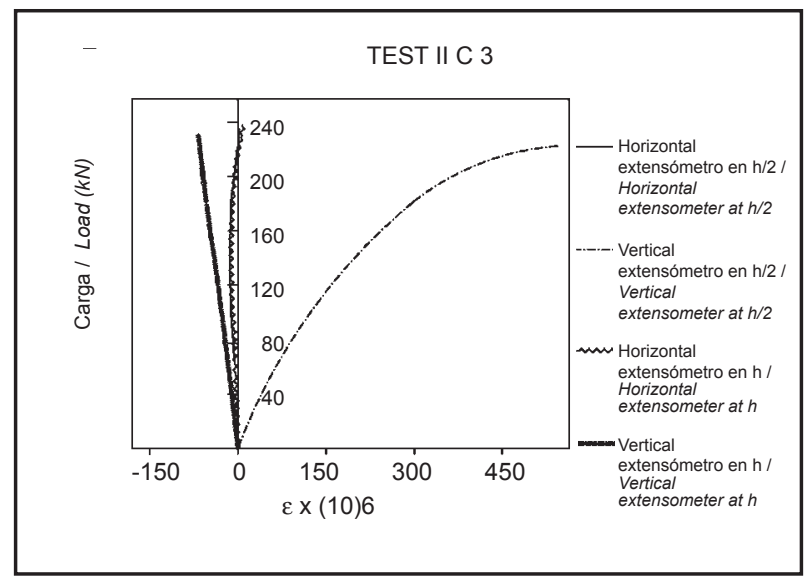

Figura 11. Curva Carga-Deformación. Probeta C3 Test II. Figure 11. Load-deformation behavior of specimen C3 during Test II.

En particular, en relación al ensayo de pull-out se observó que incluso bajo valores de carga moderadas, se producía el inicio de formación de una fisura en la parte superior del cilindro reforzado. Durante el desarrollo del ensayo, dicha fisura tendía a abrirse y a prolongarse a lo largo del cilindro hasta la parte inferior del mismo.

Para entender mejor el comportamiento mecánico que dio lugar a este fenómeno, se ha analizado lo que sucedía en un anillo de poca altura próximo a la fisura.

Se debe destacar que dado que en la parte superior del anillo, $T_{z r}$ son nulos, las tensiones tangenciales deben ser nulas también en la parte inicial de la interfaz. Por lo tanto, la parte inicial del núcleo debe estar sometida a un estado de tensiones de compresión uniforme, y transmitirá tensiones radiales al anillo de refuerzo.

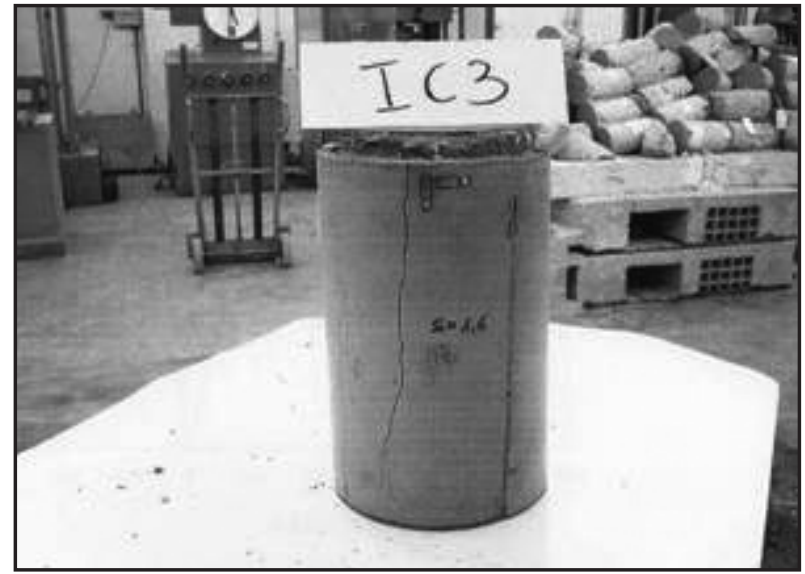

Figura 10. Probeta C3 al final del Test I. Figure 10. Specimen C3 at the end of Test I.

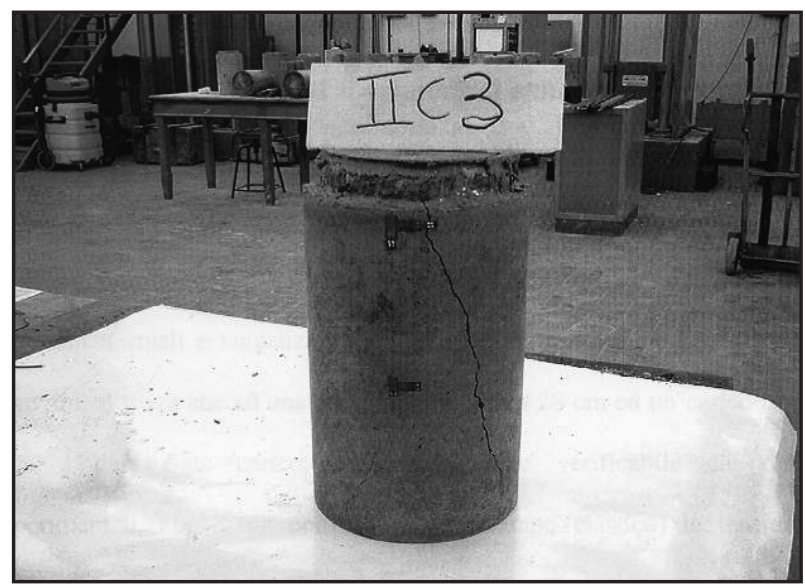

Figura 12. Probeta $\mathrm{C} 3$ al final del Test II. Figure 12. Specimen C3 at the end of Test II.

In particular, with reference to the pull-out test, it was noted that even under moderate loads a crack has triggered beginning at the upper edge of the reinforcing cylinder. During the evolution of the test such crack not only opened, but developed along the height up to the lower edge of the reinforcement.

To better understand the mechanical behavior which gave rise to this phenomenon, it has been studied what happens in a ring of small height close to the crack.

It is noted that since in the upper edge of the ring $\mathrm{T}_{z r}$ are null, the shear stress is null too on the initial part of the interface. Therefore, the first part of the core appears to be uniformly compressed and transmits radial pressures to the reinforcement ring. 
Bajo esta hipótesis, en relación a la carga de inicio de fisura, se han evaluado las tensiones en el anillo de refuerzo mediante un modelo aproximado, observándose que las tensiones excedían los valores resistentes del material, obtenidos mediante el ensayo de flexión ("bending test") en una probeta prismática $(4 \times 4 \times 16 \mathrm{~cm})$.

Los valores experimentales de la resistencia a tracción obtenidos a flexión son iguales a:

- $f_{c f m}$ aproximado $=3,5 \mathrm{~N} / \mathrm{mm}^{2}$ para el mortero EMACO S88.

- $f_{c f m}$ aproximado $=4,5 \mathrm{~N} / \mathrm{mm}^{2}$ para el mortero EMACO S150 CFR.

Estos valores han sido comparados con los resultados obtenidos mediante el método analítico desarrollado en el apartado 4,2, siendo dichos valores muy similares entre sí.

El modelo analítico aproximado consiste en considerar una muestra de poca altura próxima al borde superior, e imponer la condición de contorno para obtener el valor de $\sigma_{a n}$, de tal forma que $u_{m}=u_{r}$, siendo el subíndice $m$ el relacionado con el núcleo, y el subíndice $r$ el relacionado con el refuerzo.

\section{MODELO ANALÍTICO}

\subsection{Introducción al modelo analítico}

El objetivo del análisis fue estudiar el comportamiento de cilindros de hormigón reforzados con morteros reoplásticos. En el presente trabajo, por lo tanto, se han considerado materiales con diferentes módulos elásticos.

En el presente estudio, el modelo considerado debe cargarse de tal forma que permita comparar los resultados experimentales con los obtenidos de forma analítica.

Para el análisis analítico, se ha considerado la Tipología de refuerzo $C$ debido a que el problema de la adherencia entre el núcleo interior de hormigón y el mortero reoplástico se puede estudiar mejor.

El estudio se basa en el método clásico Ritz-Galerkin, con el objetivo de determinar la interacción entre los diferentes materiales a través de una formulación aproximada, útil para obtener las soluciones del problema elástico.

En la formulación, se ha asumido que las funciones contienen valores constantes, y se ha impuesto como condición para determinar el valor de dichas constantes, el criterio de la energía potencial mínima.
Under this hypothesis, with regard to the first cracking load, it has been evaluated the stress of the annular reinforcement with an approximate model, observing that the stress exceeded the tensile strength of the reinforcing material, which was obtained with a bending test on a prismatic specimen $(4 \times 4 \times 16 \mathrm{~cm})$.

The experimental values of the tensile strength in bending are equal to:

- approximately $f_{c f m}=3.5 \mathrm{~N} / \mathrm{mm}^{2}$ for mortar EMACO S88;

- approximately $f_{c f m}=4.5 \mathrm{~N} / \mathrm{mm}^{2}$ for mortar EMACO S150 CFR.

These values have been compared with the results obtained by the analytical procedure developed in paragraph 4.2 , which gave back very similar values.

The approximate analytical model consists in considering a small height of the specimen near the upper edge and in imposing the congruence equation $u_{m}=u_{r}$, indicating with $m$ the core and with $r$ the reinforcement, in order to obtain $\sigma_{a n}$.

\section{ANALYTICAL MODEL}

\subsection{Results of the tests}

The objective of the analysis was to study the behavior of concrete cylinders reinforced with rheoplastic mortars. In the present study, therefore, materials with different elastic moduli have been considered.

In the present analysis the model to be considered must be loaded in the way to allow a comparison between the experimental and analytical approaches.

It has been considered a type $C$ specimen because the problem of adherence between the inner concrete core and the rheoplastic mortars could be better studied.

The study is based on the classic Ritz-Galerkin method with the aim to determine the interaction between different materials through an approximate formulation useful to obtain the solutions of the elastic problem.

In the formulation, functions containing constant values have been assumed and the minimum potential energy has been imposed to determine these constants. 
Los valores obtenidos para las constantes pueden introducirse dentro de las funciones de desplazamientos para regresar al campo de tensiones (una mayor cantidad de constantes produce una solución menos aproximada).

En este proceso se ha utilizado un polinomio con más constantes; además, se ha definido la ecuación de compatibilidad en las interfaces, y dos diferentes polinomios para el contorno exterior del anillo y la zona interna del núcleo.

Concretamente, las condiciones impuestas proporcionan la continuidad de fuerzas y desplazamientos en la interfaz.

\subsection{Símbolos}

$\mathrm{T}_{r}=\mathrm{T}_{m}=f, u_{r}=u_{m}=g$ : tensión debida al rozamiento y/o adherencia.

$\mathrm{R}_{\mathrm{C}}$ : Resistencia de compresión.

E : Módulo de elasticidad longitudinal.

$r, \theta, z:$ coordenadas cilíndricas.

$v$ : coeficiente de Poisson.

$u_{r}$ : Desplazamiento del núcleo central.

$u_{a n}$ : Desplazamiento del refuerzo.

$\sigma_{a n}:$ tensión circunferencial.

$\sigma_{r}$ : tensión horizontal del cilindro interior.

$\varepsilon_{r}$ : deformación del núcleo central.

$\varepsilon_{a n}$ : deformación del refuerzo circunferencial.

$\sigma_{V}:$ tensiones verticales del cilindro.

$s$ : espesor del refuerzo.

\subsection{Modelo analítico aproximado}

El modelo consiste en considerar el área de la probeta próxima al borde e imponer la ecuación de compatibilidad entre los desplazamientos del núcleo central $u_{r}$ y los desplazamientos de la zona reforzada $u_{a n}\left(u_{r}=u_{a n}\right)$ con el objeto de obtener la tensión anular $\sigma_{a n}$. El sufijo "an" se refiere al refuerzo anular.

En la Figura 13, r es el radio del cilindro interior, mientras $R$ es el radio de la línea media del anillo exterior. Por otro lado, en la misma figura, las tensiones horizontales en el anillo central, $\sigma_{r}$, las tensiones verticales, $\sigma_{v}$ y el espesor $s$ del refuerzo son también conocidos.

El desplazamiento radial de núcleo central puede expresarse como [1]:
The values obtained for the constants can then be inserted into the displacement functions in order to go back to the stress field (a larger amount of constants leads to a less approximate solution).

In this process a polynomial with more constants has been assumed; then the congruence equations have been defined on the interfaces and, for the outer ring and the inner core, two different polynomials have been considered.

In detail, the conditions imposed have provided the continuity of strengths and displacements at the interface.

\subsection{Symbols}

$\mathrm{T}_{r}=\mathrm{T}_{m}=f, u_{r}=u_{m}=g$ : friction and/or adherence strength

$R_{C}$ : compressive strength

$E$ : longitudinal modulus of elasticity

$r, \theta, z:$ cylindrical coordinates

$v$ : Poisson's ratio

$u_{r}$ : radial displacements of the central core

$u_{a n}:$ radial displacements of the reinforcement

$\sigma_{a n}:$ annular stress

$\sigma_{r}$ : horizontal stress on the inner cylinder

$\varepsilon_{r}$ : radial deformation of the inner cylinder

$\varepsilon_{a n}$ : deformation of the annular reinforcement

$\sigma_{v}:$ vertical stress on the inner cylinder

$s$ : thickness of the reinforcement

\subsection{Analytical approximate model}

The model consists in considering the area of the specimen next to the edge and in imposing the equation of congruence between the displacements of the central core $u_{r}$ and those of the reinforcement $u_{a n}\left(u_{r}=u_{a n}\right)$ so as to obtain the annular stress $\sigma_{a n}$. The subscript "an" refers to annular reinforcement.

In Figure $13, r$ is the radius of the internal cylinder, while $R$ is the radius of the mean line of the external ring. Moreover, in the same figure, the horizontal stress on the internal cylinder, $\sigma_{r}$, the vertical stress, $\sigma_{v}$, and the thickness $s$ of the reinforcement are also shown.

The radial displacements of the central core can be written as [1]:

$$
u_{r}=\varepsilon_{r} r
$$

donde el valor de la deformación puede expresarse como [2]:

$$
\varepsilon_{r}=\frac{1}{E_{c}}\left(\sigma_{r}-v \sigma_{v}\right)
$$


En [2] $\mathrm{E}_{\mathrm{C}}$ es el módulo elástico de Young del material del cilindro interior.

Para facilitar las operaciones de sustitución y la formulación de las expresiones anteriores, el valor de la deformación anular $\varepsilon_{a n}$ se puede escribir en función del desplazamiento anular y del radio de la probeta $(R)[3]$ :
In [2] $E_{C}$ is the Young's elastic modulus of the material of the inner cylinder.

To facilitate replacement operations and the elaboration of the previous expressions, the annular deformation can is written as function of the annular displacements and the radius of the specimen $(R)$ [3]:

$$
\varepsilon_{a n}=\frac{d l-d L}{d L}=\frac{\left(R+u_{a n}\right) d \theta-R d \theta}{R d \theta}=\frac{u_{a n}}{R}
$$

Las tensiones anulares pueden expresarse como [4]:

The annular stress [4]:

$$
\sigma_{a n}=E_{a n} \varepsilon_{a n}=\frac{E_{a n} u_{a n}}{R}=\frac{N}{s \cdot 1}
$$

donde $E_{a n}$ es el módulo elástico del material correspondiente a la zona del anillo exterior, $N$ es la fuerza resultante en la porción del aniño analizada, y 1 es el valor unitario de la longitud del cilindro considerado.

De [4] es posible obtener el valor de la fuerza $N$ en el refuerzo [5]: where $E_{a n}$ is the elastic modulus of the material of the external annular ring, $N$ is the total force on the considered portion of the ring and 1 is the unity length of the cylinder.

From [4] it is possible to obtain the value of the force $N$ on the reinforcement [5]:

$$
N=\frac{E_{a n} u_{a n} s \cdot 1}{R}
$$

Considerando la fórmula de Mariotte, es posible escribir N como [6]:

Considering the Mariotte formula it is possible to write $\mathrm{N}$ as [6]:

$$
N=\frac{\sigma_{r} 2 r \cdot 1}{2}=\sigma_{r} r \cdot 1
$$

De [5] y [6] podemos obtener la siguiente expresión: [7]

From [5] and [6] we get to the following expression [7]:

$$
\frac{E_{a n} u_{a n} s \cdot 1}{R}=\sigma_{r} r \cdot 1
$$

pudiendo expresarse el desplazamiento anular como [8]:

and it is possible to write the annular displacements as [8]:

$$
u_{a n}=\frac{\sigma_{r} r R}{E_{a n} s}
$$

Imponiendo la ecuación de continuidad $u_{m}=u_{a n}$ y susti- $\quad$ Imposing the equation of congruence $u_{m}=u_{a n}$ and substuyendo [2] y [8] resulta [9], [10] y [11] : tituting [2] and [8] it results [9], [10] and [11]:

$$
\begin{gathered}
\frac{\sigma_{r} r R}{E_{a n} s}=\frac{r}{E_{c}}\left(\sigma_{r}-v \sigma_{v}\right) \\
\sigma_{r}=\frac{v \sigma_{v}}{\left(1-\frac{E_{c} R}{E_{a n} s}\right)}
\end{gathered}
$$




$$
N=\sigma_{r} r \cdot 1=\frac{r v \sigma_{v} \cdot 1}{\left(1-\frac{E_{c} R}{E_{a n} s}\right)}
$$

Por lo tanto, se pueden expresar las tensiones anulares actuando sobre el refuerzo según la Figura 13, como una función de las tensiones verticales del cilindro interior $\left(\sigma_{V}\right)$ [12]:

$$
\sigma_{a n}=\frac{N}{s \cdot 1}=\frac{r v \sigma_{v}}{\left(s-\frac{E_{c} R}{E_{a n}}\right)}
$$

Considerando la carga de rotura de la probeta I C1 de valor $251 \mathrm{kN}$ y asumiendo:

$$
\begin{aligned}
& r=8 \mathrm{~cm} \\
& R=9 \mathrm{~cm} \\
& \mathrm{v}=0,24 \text { (para el mortero reoplástico y el hormigón) } \\
& \mathrm{s}=2 \mathrm{~cm} \\
& \mathrm{E}_{\mathrm{C}}=26.000 \mathrm{~N} / \mathrm{mm}^{2} \\
& \mathrm{E}_{\mathrm{an}}=25.000 \mathrm{~N} / \mathrm{mm}^{2} \\
& \text { se obtiene que }[13]:
\end{aligned}
$$

The annular stress acting on the reinforcement, therefore, could be expressed by the following (Figure 13), as function of the vertical stress in the inner cylinder $\left(\sigma_{v}\right),[12]$ :

\section{Considering the cracking load of the specimen I C1 that is equal to $251 \mathrm{kN}$ and assuming:}

$$
\begin{aligned}
& r=8 \mathrm{~cm} \\
& R=9 \mathrm{~cm} \\
& v=0.24 \text { (for both concrete and rehoplastic mortar) } \\
& s=2 \mathrm{~cm} \\
& E_{c}=26000 \mathrm{~N} / \mathrm{mm}^{2} \\
& E_{\text {an }}=25000 \mathrm{~N} / \mathrm{mm}^{2} \\
& \text { it results }[13]:
\end{aligned}
$$

$$
\sigma_{a n}=\frac{1.92 \cdot \sigma_{v}}{2-9.36}=-0.26 \sigma_{v}
$$

con el siguiente valor de la tensión normal que actúa en el núcleo [14] (Figura 13):

with the following value of the normal stress acting in the core (Figure 13), [14]:

$$
\sigma_{v}=-\frac{251000 \mathrm{~N}}{20100 \mathrm{~mm}^{2}}=-12.5 \frac{\mathrm{N}}{\mathrm{mm}^{2}}
$$

Sustituyendo [14] en [13], las tensiones anulares de tracción actuando en la zona de refuerzo serán [15]:
Substituting [14] in [13], the annular tensile stress acting on the reinforcement is [15]:

$$
\sigma_{a n}=3.26 \frac{\mathrm{N}}{\mathrm{mm}^{2}}
$$

Se puede observar cómo el resultado analítico es comparable con los valores experimentales obtenidos de resistencia a tracción para el mortero tipo EMACO S88.

También se consideró el caso en el que la fisura se produjese por tensiones de pandeo, asumiendo que a la altura del fuerzo exterior igual a $h / 2$, las tensiones normales eran cero. La Figura 14 muestra el esquema de transmisión de cargas en la probeta.

Si consideramos la probeta II C 2, las tensiones normales $\sigma_{z z}$ se pueden evaluar multiplicando el módulo elástico longitudinal $\mathrm{E}_{\mathrm{c}}$ por el valor de la deformación vertical medida a través de la galga extensométrica dispuesta a h/2.
The result is comparable with the experimental values of the strength of the material EMACO S88 constituting the specimen.

It was also considered the case when the cracks are produced by the buckling stresses, assuming that at a height of the external reinforcement equal to $h / 2$ the average of the normal stresses acting on the central core is zero. Figure 14 represents a scheme of the load transmission in a specimen.

Considering specimen II C 2, the normal stress $\sigma_{z z}$ has been evaluated multiplying the longitudinal modulus of elasticity $E_{c}$ for the value of the vertical deformation measured by the vertical strain-gauge applied at $h / 2$. 


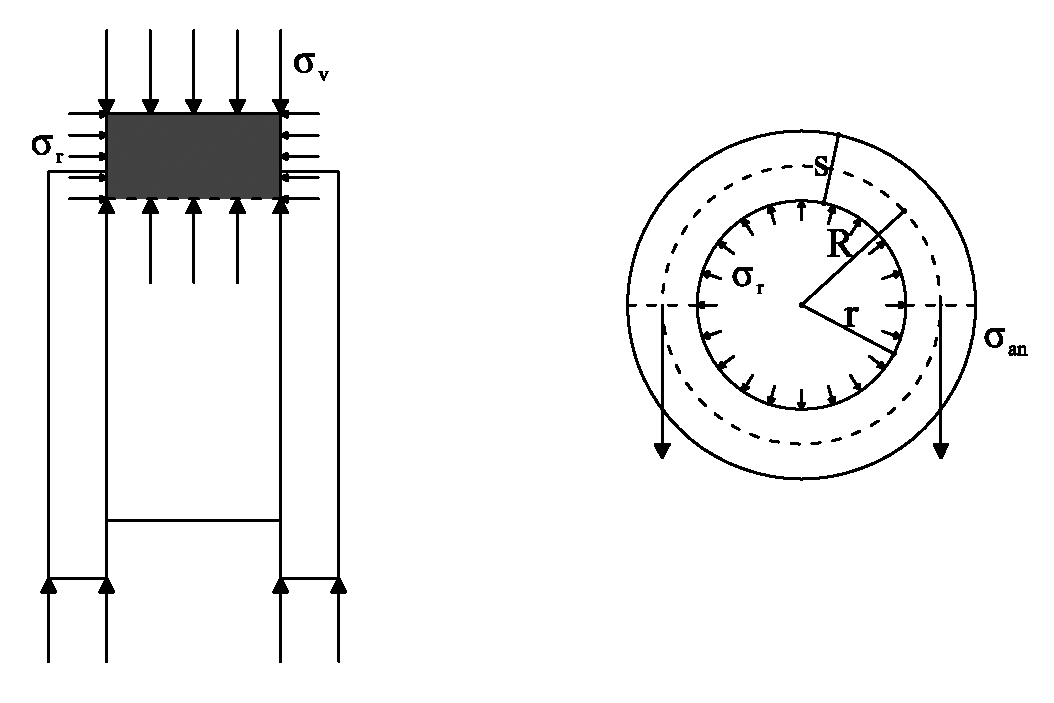

Figura 13. Modelo analítico aproximado y fuerzas actuantes. Figure 13. Analytical approximate model and acting forces.

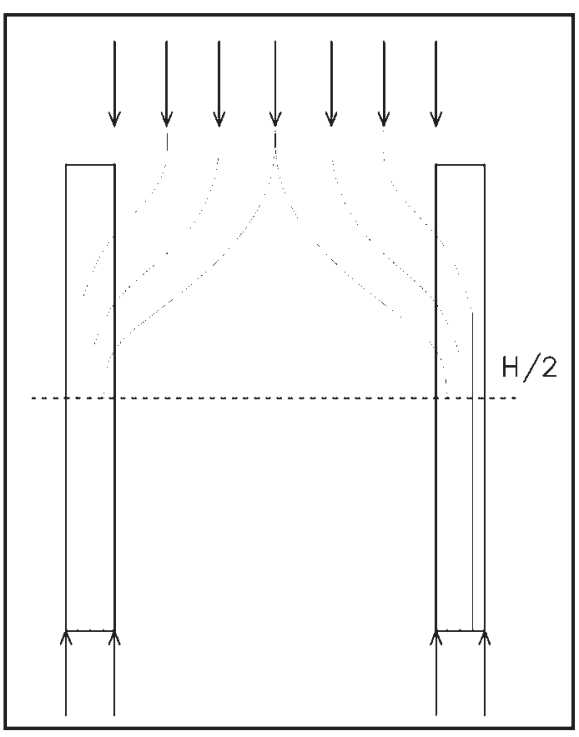

Figura 14. Esquema del flujo de cargas en la probeta.

Figure 14. Scheme of the load path in the specimen.

Valor de [16]:

Value of [16]:

$$
\begin{gathered}
\sigma_{z z}^{(1)} \\
\sigma_{z z}^{(1)}=E_{c} \varepsilon_{z z}=25000.450 \times 10^{-6}=11.25 \mathrm{~N} / \mathrm{mm}^{2}
\end{gathered}
$$

Finalmente, aplicando la siguiente expresión y considerando la tensión normal de la zona anular de refuerzo, $\sigma_{z z^{(1)}}$, y la tensión normal en la matriz, $\sigma_{z z^{(2)}}$, es posible conocer el valor de la tensión, $\sigma_{z z^{2}}[17][18]$ :

$$
\begin{gathered}
\frac{\sigma_{z z}{ }^{(1)}+\sigma_{z z}{ }^{(2)}}{2} \cdot s \cdot\left(2 \pi \cdot \frac{r+R}{2}\right)=N_{\text {rott }} \\
\sigma_{z z}{ }^{(2)}=37.83 \mathrm{~N} / \mathrm{mm}^{2}
\end{gathered}
$$

Finally by applying the following formula and considering the normal stress of the annular reinforcement, $\sigma_{z z}(1)$, and the normal stress in the matrix, $\sigma_{z z}{ }^{(2)}$, it is possible to know the stress, $\sigma_{z z}{ }^{(2)}[17],[18]$ :

El valor obtenido, el cual representa el valor de la tensión en la interfaz, puede compararse con la tensión de compresión del refuerzo.

Este valor es muy inferior al valor asociado a la resistencia a compresión del mortero tipo EMACO CFR S150, de valor $60 \mathrm{~N} / \mathrm{mm}^{2}$.

Además, si consideramos los datos del modelo teórico, es evidente que el valor de las tensiones $\sigma_{z z}$ serán máximas para $z=0$, e irán reduciéndose a medida que aumente $z$.

\section{CONCLUSIONES Y ESTUDIOS FUTUROS}

En el presente artículo se han llevado a cabo una serie de ensayos con el objetivo de conocer el comportamiento en términos de resistencia estructural, de probetas de hormigón reforzadas con morteros reoplásticos.
The value obtained, which also represents the stress on the interface, can be compared to the reinforcement compressive strength.

This value is low enough if compared to the compressive strength of EMACO CFR S150 mortar that is equal to 60 $\mathrm{N} / \mathrm{mm}^{2}$.

Moreover, considering also the data of the theoretical model, it is evident that the stresses $\sigma_{z z}$ are maxima for $z=0$ and they tend to reduce as $z$ increases.

\section{CONCLUSIONS AND FUTURE STUDY}

In the present paper a series of laboratory tests have been carried out to know the performance, in terms of structural strength, assessing the response of concrete specimens reinforced with rheoplastic mortars. 
El estudio desarrollado en el presente artículo es un trabajo preliminar enmarcado dentro de una investigación mayor relacionada tanto con la durabilidad de los materiales de construcción (aspecto particularmente importante desde el punto de vista de la tecnología de la construcción), como la compatibilidad de diferentes materiales desde el punto de vista de las propiedades mecánicas, físicas y químicas.

De ello se deduce que en el refuerzo de estructuras con morteros, se debe prestar mucha atención a la zona de refuerzo. Especialmente cuando esta no está confinada por una viga y/o losa. Por lo tanto, un espesor adecuado y un correcto refuerzo para el confinamiento transversal, sería necesario para evitar la rotura frágil del mortero, aunque este último pueda tener una elevada resistencia a la compresión.

Por otro lado, la formulación propuesta en el modelo analítico para determinar las tensiones en la interfaz ha mostrado que con pocos pasos analíticos, es posible determinar las tensiones que se producen en la zona crítica de los elementos de hormigón reforzados con morteros reoplásticos.

En el futuro se realizarán una mayor cantidad de ensayos sobre probetas con diferentes espesores de refuerzo para estudiar la influencia del motero en el comportamiento global de la probeta reforzada.

\section{AGRADECIMIENTOS}

Al personal del laboratorio "M. Salvati", y en particular a Francesco Paparella por su ayuda durante los ensayos.
The study developed in the present paper is preliminary on a wider research on a complex issue that affects both the durability of building materials (particularly relevant aspect of the building technology) and the fundamental matter of the compatibility of different materials for the chemical, physical and mechanical properties.

It follows, therefore, that in the structural reinforcement with mortars close attention must be paid to the area of reinforcement, especially when it is not confined by a beam and/or a slab. Therefore, a suitable thickness and an appropriate confining transverse reinforcement would be needed to avoid a brittle fracture of the mortar, although the latter may have a high compressive strength.

Moreover the formulation of a simplified analytical model for determining the interface stress has shown how, with few analytical steps, it is possible to determine the stresses acting in the most critical areas of concrete elements reinforced with rheoplastic mortars.

In the future more tests on specimens with different thickness of the reinforcement will be performed to study the influence of the mortar on the behavior of the entire reinforced specimen.

\section{ACKNOWLEDGEMENTS}

The staff of the Laboatory "M. Salvati" and, in particular, Mr Francesco Paparella is gratefully acknowledged for their help in the tests.

\section{BIBLIOGRAFÍA / BIBLIOGRAPHY}

(1) Bentayeb, F.; Ait Tahar, K.; Chateauneuf, A.: "New technique for reinforcement of concrete columns confined by embedded composite grid", Constr. Build. Mater., vol. 22, issue 8 (2008), pp. 1624-1633, ISSN: 0950-0618.

(2) Foti, D.: "Preliminary analysis of concrete reinforced with waste bottles PET fibers", Constr. Build. Mater., vol. 25, issue 4 (2011), pp. 1906-1915, ISSN: 0950-0618, doi:10.1016/j.conbuildmat.2010.11.066.

(3) Foti, D.: "Use of recycled waste pet bottles fibers for the reinforcement of concrete", in press on Composite Structures, vol. 96, (2013), pp. 396-404, ISSN: 0263-8223, doi: 10.1016/j.compstruct.2012.09.019.

(4) Fukuyama, K.; Higashibata, Y.; Miyauchi, Y.: "Studies on repair and strengthening methods of damaged reinforced concrete columns", Cem. Concr. Comp., vol. 22, issue 1 (2000), pp. 81-88. http://dx.doi.org/10.1016/S0958-9465(99)00044-X

(5) Steif, P. S.; Hoysan, S. F.: "On load transfer between imperfectly bonded constituents", Mechanics of Materials, vol. 5, issue 4 (1986), pp. 375-382. http://dx.doi.org/10.1016/0167-6636(86)90041-4

(6) Lee, Ho J.; Aschleim, M.; Hernajndez-Montes, E.; Gil-Martan, L.M.: "Optimum RC column reinforcement considering multiple load combinations", Structural and Multidisciplinary Optimization, vol. 39, issue 2 (2009), pp. 153-170. http://dx.doi.org/10.1007/s00158-008-0318-4

(7) Liu, J.; Foster, S.J.: "A three-dimensional finite element model for confined concrete structures", Computers and Structures, vol. 77, issue 5 (July 2000), pp. 441-451. http://dx.doi.org/10.1016/S0045-7949(00)00007-9

(8) Hadi, M.N.S.; Li, J.: "External reinforcement of high strength concrete columns", Composite Structures, vol. 65, issue 3-4 (Sept. 2004), pp. 279-287, ISSN: 0263-8223. 